\title{
Viešųjų projektų vertinimas kaštų naudos analizès metodu: kritiškas požiūris
}

\section{Jurgita Baranauskienè}

Aleksandro Stulginskio universitetas,

Universiteto g. 10,

LT-53361 Akademija, Kauno r.

El.paštas: jurgita.baranauskiene@asu.lt
Viešieji investiciniai projektai, skirtingai nei verslo projektai, negeneruoja grynuju pajamų (arba generuoja nepakankamai, kad būtų finansiškai pagrịsti), o kuria socialinę naudą visuomenei. Tokių projektų pagrindinis tikslas - viešųjų poreikių tenkinimas: socialinių, ekonominių, aplinkosauginių. Plačiąja prasme - tai visuomeninè-socialinè nauda. Prieš priimant investicinị sprendimą, kiekvienas projektas turi būti įvertintas ir pagrịstas. Viešųjų projektų vertinimui plačiai naudojama kaštu naudos analizė nevisiškai atitinka viešųjų projektų pagrindinę koncepciją. Šio tyrimo tikslas - atskleisti kaštų naudos analizès metodo, naudojamo viešujų projektų vertinimui, privalumus ir trūkumus, apibrèžti problemų lauką kitiems galimiems moksliniams tyrimams - kaštų naudos analizès metodo tobulinimui ar naujų metodų, viešųjų projektų vertinimui, kūrimui.

Raktažodžiai: kaštų naudos analizė, viešasis projektas, socialinė nauda, socialinė diskonto norma

\section{IVADAS}

Europos Sąungos (ES) bei Lietuvos reglamentai reikalauja, jog visi viešieji projektai, pretenduojantys gauti finansavimą iš ES struktūrinių fondų ar Sanglaudos fondo, būtų ịvertinti kaštų naudos analizès (angl. Cost Benefit Analysis) metodu. Viešųjų projektų tikslai susiję ne su finansinių pajamų kūrimu, o socialinès gerovès prasme - socialine nauda visuomenei, kurią sudètinga išmatuoti bei išreikšti piniginiais vienetais (Van De Walle, 2002). Socialinès gerovès užtikrinimo investicijos yra nukreiptos kurti sporto, viešojo maitinimo, pramogu bazes, gerinti medicinini aptarnavimą, sveikatos priežiūrą, užtikrinti visuomenès narių saugumą, plètoti mažamečių vaikų priežiūros ir auklejjimo sistemą, puoselèti aplinkosaugą, skatinti ekologiją ir pan.

Projektų rengejų, vykdytojų ir ES paramą administruojančių institucijų patogumui yra parengtos ne vienos investicinių projektų vertinimo kaštų naudos analizès metodu gairès, kuriomis vadovaujantis investiciniai kaštai ir laukiama socialinè nauda ịvertinama grynąją dabartine verte (angl. Net Present Value). Mokslinèje literatūroje dažnai keliamas klausimas - ar sudètingo, $\mathfrak{z}$ ateitị orientuoto ir daug nežinomujų turinčio viešojo projekto vertinimas kaštų naudos analizès metodu yra patikimas? Aktualiausia kaštų naudos analizès problema - socialinès naudos kokybinių rodiklių išraiška kiekybiniais matais bei piniginès vertès suteikimas piniginiais matais nepamatuojamiems rodikliams (pvz., žmogaus gyvybei). Reikia pripažinti, kad viešojo projekto vertinimas kaštų naudos analizès metodu gali būti šališkas - net ir atlikus geriausią i̇manomą kaštų naudos analizę neišsprendžiamos problemos, t. y. vertinant viešajj projektą nesuskaičiuojama visa projekto kuriama socialinè nauda, kuri yra pagrindinis siekiamas viešojo projekto tikslas. Todèl viešuosius projektus vertinant kaštų naudos analizès metodu reikia suprasti ir pabrèžti akivaizdų šio metodo ribotumą.

Tyrimo objektas - viešųų projektų vertinimas kaštų naudos analizès metodu.

Tyrimo tikslas - išanalizavus kaštų naudos analizès metodinius ypatumus, atskleisti viešųju 
projektų vertinimo kaštų naudos analizès metodu privalumus ir trūkumus bei socialinès naudos ivertinimo ir socialinès diskonto normos nustatymo problematiką.

Tyrimo uždaviniai:

1. Apžvelgti kaštų naudos analizès metodinius ypatumus vertinant viešuosius projektus.

2. Detalizuoti viešųjų projektų vertinimo kaštų naudos analizès metodu privalumus bei trūkumus.

3. Atskleisti viešųjų projektų socialinès naudos išmatavimo bei socialinès diskonto normos nustatymo problematiką.

Tyrimo metodai. Siekiant užsibrežto tikslo ir ji suponuojančių uždavinių buvo taikyta mokslinès literatūros analizè, informacijos sisteminimas, lyginimas, apibendrinimas.

Tyrimo apribojimas - straipsnyje neanalizuojama kaštų naudos analizės metodo pinigų srautų formavimo problematika.

\section{Kaštų naudos analizės metodo ypatumai vertinant viešuosius projektus}

Mokslininkai, pradejję diskutuoti apie viešųjų projektų vertinimo problematiką, įvardino viešųjų projektų socialinès naudos svarbą, tačiau pripažino, kad vargu galima atrasti ją įvertinančią funkciją. Viešąsias investicijas buvo siūloma vertinti sukurto turto verte ar pajamomis suteikiant projektams svorius (Eckstein, 1958, Margalin, 1967; McGuire, Garn, 1969). Šiuo metu viešųjų projektų vertinimui plačiausiai naudojamas kaštų naudos analizès metodas, kuris leidžia ịvertinti ir neduodančius tiesioginių pajamų projektus, teikiančius tik socialinę naudą.

Kaštų naudos analizès teorinius principus išsamiai analizavo R. Sugden, A. Williams (1978); A. Ray (1984); N. Hanley, P. O. Johansson (1993); C. L. Spash (1993); A. Boardman et al. (2006); D. W. Pearce (2006); H. S. Rosen, T. Gayer (2008) ir kt. autoriai. Kaštų naudos analizès metodas smulkiai išnagrinètas ES bei Lietuvos metodiniuose dokumentuose viešųjų projektų rengejjams, vertintojams bei vykdytojams.

Kaštų naudos analize - sisteminis kiekybinis investicinių projektų vertinimo metodas, leidžiantis nustatyti ir įvertinti ilgalaikius finansinius, ekonominius bei socialinius projektu padarinius - naudą ir žalą. Pagrindinis šios analizès tikslas - parodyti projekto naudą (tiek finansinę, tiek socialinę), palyginti su investicijomis, kartu ivvertinti projekto igyvendinimo riziką. Socialine projekto igyvendinimo nauda pasireiškia teigiamu ekonominiu, socialiniu, aplinkosauginiu poveikiu tam tikrai bendruomenei, regionui, šaliai. Esminiai kaštų naudos analizès metodo principai:

- lyginamos bent dvi alternatyvos: „be projekto“ ir „su projektu“ (alternatyvų gali būti ir daugiau);

- alternatyva „be projekto“ yra vertinimo atskaitos taškas;

- finansiniai ir ekonominiai rodikliai parodo skirtumą tarp vertinamo investicinio sprendimo ir alternatyvos „be projekto“;

- $\quad$ kadangi pagrindinis išlaidų naudos analizè naudos rodiklis yra ekonominè nauda, pasirenkamas projekto igyvendinimo variantas, duodantis didžiausią ekonominę naudą (Baranauskienè, 2004).

Kaštų naudos analizè apima projekto finansini, ekonomini ir rizikos vertinimą. 1 pav. pateikti kaštụ naudos analizès sudedamųjų dalių pagrindiniai tikslai.

Finansinès analizès tikslas yra nustatyti projekto finansinę vidinę grąžos normą (ịvertinus projekto grynuosius pinigų srautus) (IRR, angl. Internal Rate of Return) investicijoms ir nuosavam kapitalui bei atitinkamą projekto finansinę grynąją dabartinę vertę (NPV, angl. Net Present Value). Finansinè analizè susideda iš etapų, kuriuose apskaičiuojami investicijų finansiniai srautai, veiklos pajamos ir išlaidos, investicijų šaltiniai bei atliekama pinigu srautų analizè. Finansinè analizė baigiama investicijų grąžos įvertinimu (ịvertinama grynųjų projekto pajamų geba padengti investicijų kaštus, nepriklausomai nuo finansavimo šaltinio) ir projekto vidinès grąžos nuosavam kapitalui įvertinimu (nuosavas investuotas kapitalas įvertinamas kaip investuotojo kapitalas, finansinès paskolos ju grąžinimo laikotarpiu, sudètas kartu su grynuoju veiklos pinigu srautu) (Boardman et al., 2006; Rosen, Gayer, 2008; Guide..., 2008).

Viešųjų projektų vertinimo etapai kaštų naudos analizès metodu pateikti 2 pav.

Atliekant ekonomini projektų vertinimą, jeigu imanoma, siekiama nustatyti ekonominę vidinę grąžos normą ir grynąją dabartinę vertę. Šie rodikliai apskaičiuojami atliekant finansinio pinigu srauto diskontavimą, prieš tai atlikus korekcijas (PVM ir kitų netiesioginių mokesčių eliminavimas 


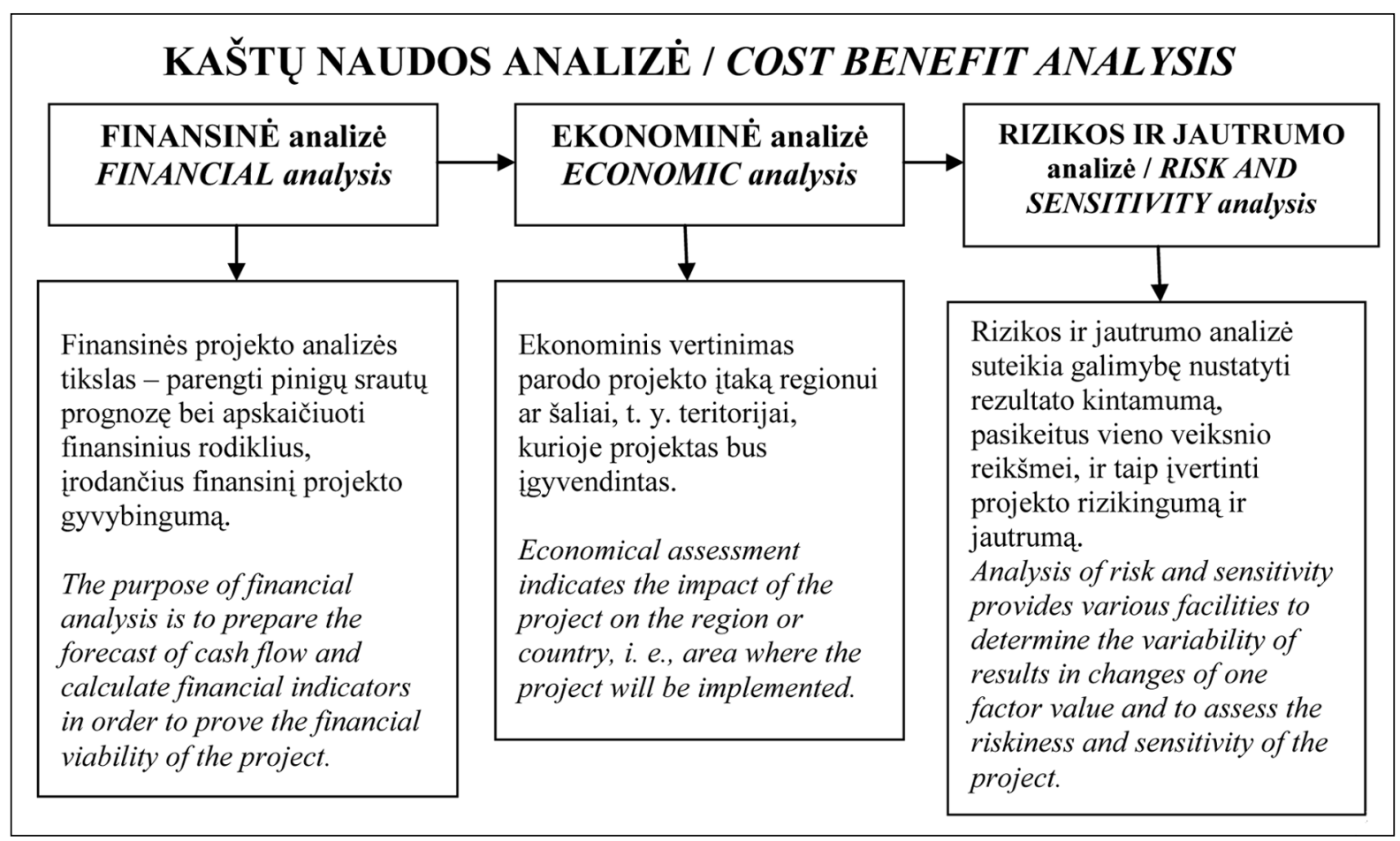

1 pav. Kaštų naudos analizès sudedamosios dalys ir jų tikslai

Fig. 1. Components of cost benefit analysis and their purposes

(tiek îplaukų, tiek išlaidų), sąnaudos ịvertinamos iskaitant visus tiesioginius mokesčius, grynųjų mokesčių darbuotojams (pvz., soc. draudimas) eliminavimas) bei ịvertinus išorini projekto povei$\mathrm{ki} \mathrm{-} \mathrm{socialinę} \mathrm{naudą} \mathrm{visuomenei.} \mathrm{Socialinè} \mathrm{nau-}$ da turi būti išreikšta pinigine išraiška ịvertinant projekto poveiki visiems visuomenès individams. Dažnai yra sudètinga tiksliai apskaičiuoti socialinę projektų naudą, kadangi sunku ją išreikšti pinigine verte.

Projekto ekonominis, socialinis, aplinkosauginis ir kt. poveikis turi būti ịvertinamas atsižvelgiant $\mathfrak{i}$ iš anksto nustatytus projekto tikslus. Pirmiausia reikia identifikuoti socialinès naudos veiksnius, kurių identifikavimas leidžia numatyti investicinès veiklos socialinius padarinius (Hanley, Spash, 1993). Vertinant projektą pagal jo mikroekonominius rodiklius ekonominè analizè gali ịvertinti projekto suderinamumą ir svarbą (siekiant konkrečių makroekonominių tikslų). Regioninès politikos srityje ekonominè analizè yra taikoma siekiant ịvertinti konkretaus viešojo projekto svarbą (siekiant ES regioninès politikos tikslų). Ekonominès analizès lygis turi būti nustatytas atsižvelgiant it visuomenę, kurią paveiks projektas. Išlaidos ir nauda gali atsirasti ir didèti ívairiais geografiniais lygiais, todèl turi būti nuspręsta, ị kokias išlaidas ir naudą bus atsižvelgiama. Tai paprastai priklauso nuo projekto masto ir taikymo srities. Galima atsižvelgti i poveikį savivaldybių, regionų, nacionaliniu ir netgi platesniu mastu.

Metodinèse gairèse projektų rengejjams, vertintojams ir vykdytojams teigiama, jog jeigu sunku ar neįmanoma atlikti socialinès naudos piniginio ivertinimo, išorinis projekto poveikis turi būti išreiškiamas kitais kiekybiniais ar kokybiniais matavimo vienetais (Guidance..., 2006; Guide..., 2008; Investicijų projektų..., 2011). Jeigu projekto metu gaunama nauda ar žala, kurios neitmanoma išreikšti pinigine išraiška, tokia nauda privalo būti apibūdinta daugiakriterinès ekonominès analizès būdu (atrinktais vienodais kokybiniais kriterijais vertinant visas investavimo alternatyvas) parodant papildomą projekto poveiki naudos gavejams. Tačiau konkrečių kaštų naudos analizès ir daugiakriterinès analizès integruotų modelių nepateikia nei metodikų kūrejjai, nei mokslininkai.

Neišmatuojamos piniginiais vienetais socialinès naudos traktavimas kaip nereikšmingas (Socialinių..., 2011), prieštarauja pagrindiniams viešųjų projektų principams, idèjoms bei tikslams - tenkinti visuomenès socialinius poreikius. 


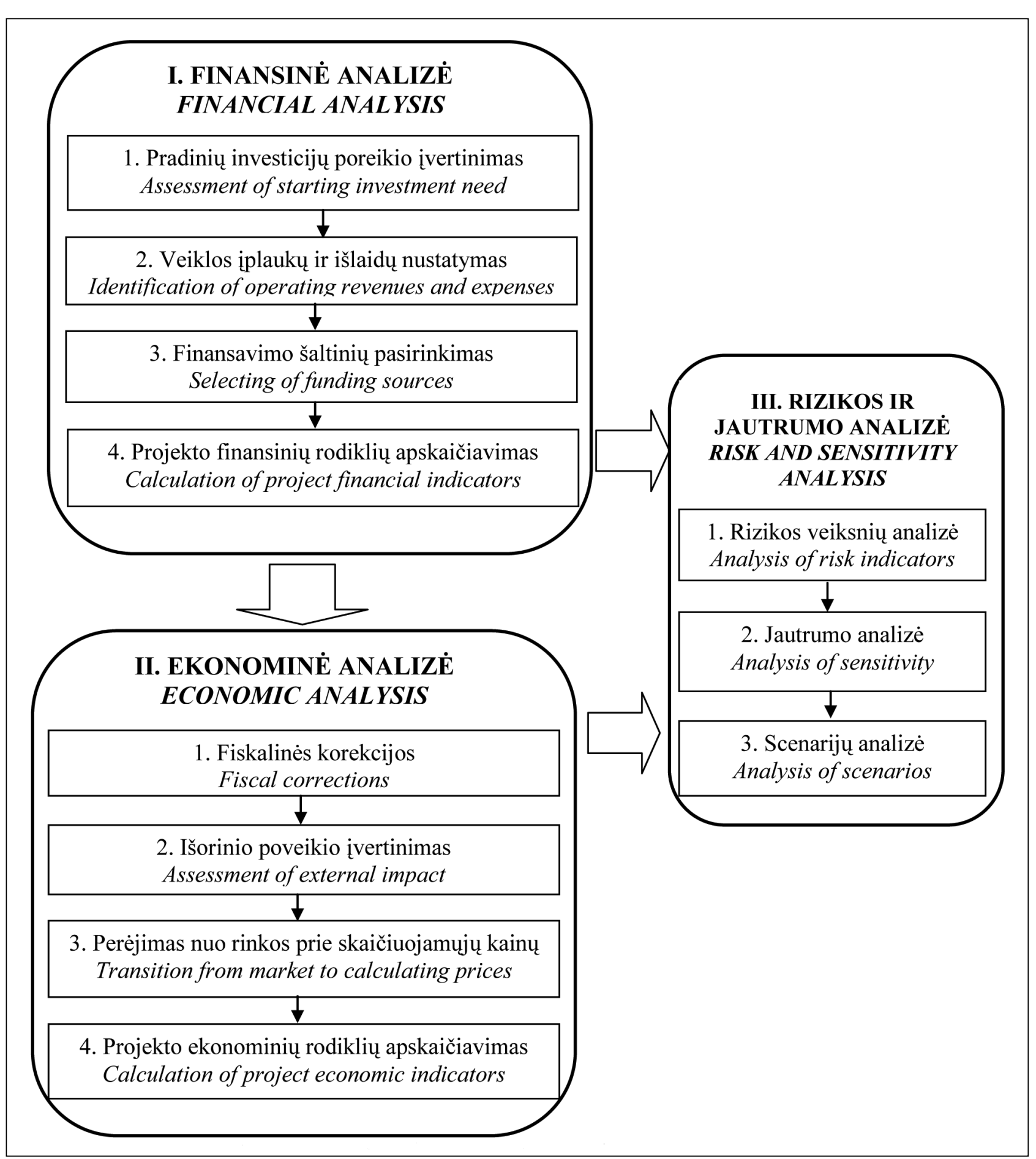

2 pav. Viešųjų projektų vertinimo kaštų naudos analizès metodu etapai (sudaryta autorès pagal Boardman et al., 2006; Guide..., 2008; Rosen, Gayer, 2008; Investicijų projektų..., 2011)

Fig. 2. Steps of cost benefit analysis in public project evaluation (prepared by the author using Boardman et al., 2006; Guide..., 2008; Rosen, Gayer, 2008; Investicijų projektų..., 2011)

Pvz., vertinant vandentvarkos projektą, kurio pagrindinis tikslas - pagerinti gyventojų gyvenimo ir darbo sąlygas rekonstruojant vandentvarkos sistemas ir užtikrinant perteklinio vandens savalaikị nuvedimą nuo dirbamų žemių bei gyvenvie- čių prieigų, gali būti vertinami tokie kiekybiniais ir kokybiniais matavimo vienetais išmatuojami socialinès naudos rodikliai:

1) teigiamo poveikio dirvožemio ir vandens ekologinèms savybėms rodiklis; 
2) teigiamo poveikio kraštovaizdžiui rodiklis;

3) rizikos užteršti aplinką sumažinimo rodiklis;

4) neigiamo poveikio gyventojams ir jų gyvenimo sąlygoms sumažinimo rodiklis;

5) projekto naudos gavejų skaičius;

6) pagerintos žemès plotas ha (Baranauskienè, Maziliauskas, 2012).

Minèti rodikliai piniginiais vienetais neišmatuojami ir î kaštų naudos analizę negali būti itraukti.

Atliekant ekonominę analizę, kai realios kainos yra iškreiptos netobulos rinkos (muitai, kvotos, apribojimai, valstybès turto nuoma mažesnèmis nei rinkos kainomis ir t. t.), o atlyginimai nèra tiesiogiai susieti su darbo produktyvumu (subsidijos, darbo biržos mokejjimai, ịsipareigojimai išsaugoti darbo vietas ir t. t.), reikia atlikti perèjimą nuo rinkos prie skaičiuojamųjų kainų nustatant perëjimo nuo rinkos prie skaičiuojamụjų verčiu faktorius (daugiklius).

Atlikus fiskalinę, išorinio poveikio įvertinimo ir perejjimo nuo rinkos prie skaičiuojamųų verčių korekciją, gauname pakoreguotą pinigų srautą, kuris leidžia apskaičiuoti ekonominę NPV ir IRR. Naudojama socialinè diskonto norma - šiuo metu iš ES struktūrinių fondų finansuojamiems projektams siūloma 5,5 \% (Guidance..., 2006).

Mokslininkai nesutaria socialinès diskonto normos nustatymo klausimu, o aktyvios mokslinès diskusijos atskleidžia dar vieną aktualią viešųjų projektų vertinimo kaštų naudos analizès metodu problemą - kokią socialinę diskonto normą pasirinkti, kai viešasis projektas planuojamas ateičiai, o socialinè nauda bus gaunama po ilgo laikotarpio?

Viešieji projektai finansinès naudos negeneruoja, todèl finansinių rodiklių apskaičiavimas nèra reikšmingas investicinio sprendimo prièmimui, o ekonominè analizè yra esminis kaštų naudos analizès etapas vertinant viešuosius projektus. Ekonominès analizès metu apskaičiuoti rodikliai yra svarbiausi pasirenkant investavimo alternatyvą, atsižvelgiant $\mathfrak{i}$ investicines išlaidas bei rizikingumą.

Ekonominè analizè atskleidžia privataus ir viešojo projekto vertinimo kaštų naudos analizés metodu skirtumus. Pirma, svarbiausias projekto rezultatas, kuris rūpi i̇monei, yra susijęs su jos pelningumu, o viešojo intereso atstovams rūpi gerokai platesnis pasekmių ratas: pvz., kuriant re- kreacinę infrastruktūrą visuomenès atstovams ne mažiau svarbūs socialiniai klausimai ir aplinkosauginiai efektai, susiję su infrastruktūros panaudojimu (itvairių socialinių grupių poreikių tenkinimas, rekreacijos paslaugu prieinamumas, kokybè, itaka visuomenès elgsenai, aplinkai ir pan.). Antra, imoné naudoja rinkos kainas, kad ịvertintu investicijas, veiklos kaštus bei laukiamą finansinę naudą. Ivardijami du atvejai, kada viešųjų projektų kuriamai socialinei naudai negalima naudoti rinkos kainų:

1) kai sukurta viešoji prekè (socialinè nauda) neparduodama rinkoje ir rinkos kaina neegzistuoja;

2) kai yra rinkos yda, t. y. rinkos kainos neatspindi tikrų projekto ribinių socialinių kaštų ar naudos. Kainos, naudojamos ivertinti projektus, turi atspindèti rinkos ydą (Rosen, Gayer, 2008).

Siekiamybė įtraukti socialinių reiškinių piniginę vertę i projektų vertinimą rodo ekonominès politikos požiūrị i aplinką, socialinę gerovę. Be to, ekonomistams ir visuomenei reikia žinoti aplinkosaugos, socialinès gerovès vertę (Hanemann, 1994). Išorinių veiksnių ịtraukimas ị kaštų naudos analizę parodo, kiek visuomenè pasiruošusi mokèti už socialinę naudą. Išsami veiksnių analizė atskleidžia projekto riziką, galimus praradimus ar sinergijas (Nooij, 2011).

Skeptikai teigia, kad tradicinė kaštų naudos analizè yra per daug ambicinga ir tuo pačiu per daug supaprastina, nes visa reikiama informacija koncentruojama ị vieną rodiklį, matuojamą piniginiais vienetais. Objektyviam sprendimų priemimui turètų būti parengta daugiau rodiklių, matuojamų ne tik piniginiais vienetais (Nyborg, 2000).

E. Hauer (2011), naudojusi kaštų naudos analizę kelių saugumui ịvertinti, kelia klausimą, kaip piniginiais vienetais išreikšti naudą visuomenei, t. y. saugumą, laiką, laisvę - šie reiškiniai neturi piniginès išraiškos. Dar sunkiau naudą diskontuoti it dabartinę vertę.

Viešieji projektai yra planuojami ateičiai, neišvengiamai sąlygojami neapibrěžtumo ir rizikos, turi būti lankstūs galimiems mikro- bei makroaplinkos pokyčiams. Kiekvieną projekto etapą veikia tam tikri rizikos veiksniai, dèl kurių galimi nukrypimai nuo norimo plano. Dèl šių priežasčių svarbu numatyti pagrindinius projekto rizikos veiksnius, priežastis, rizikos mažinimo priemones. 
Jautrumo analize nustatoma, kaip projekto ekonominių ir finansinių rezultatų kintamumą veikia tam tikri rizikos veiksniai, projekto prielaidų pasikeitimai. Ši analizė padeda išskirti kritinius kintamuosius, kurie turi didžiausią ịtaką projekto rezultatams. Scenarijų (variantų) analizè parodo, kiek atskiruose projekto igyvendinimo etapuose esant optimistiniam, labiausiai tikètinam bei pesimistiniam scenarijui keičiasi ekonominè IRR.

Rizikos įvertinimas yra labai svarbi kaštų naudos analizès dalis, kadangi ji suteikia galimybę geriau suprasti, kaip ịvertintas poveikis gali keistis, jei kai kurie pagrindiniai projekto kintamieji taptų kitokiais nei tikètasi. Išsami rizikos analizė yra patikimo rizikos valdymo strategijos pagrindas, kuris savo ruožtu įsilieja ị bendrą projekto kūrimą ir igyvendinimą. Rizikos analizè leidžia priimti alternatyvų investicinį sprendimą atsižvelgiant i galimus planuojamo projekto nepageidaujamus nuokrypius bei praradimus.

Apibendrinant galima teigti, jog kaštų naudos analizès metodas labiau tinkamas verslo projektams vertinti, o viešųuu projektų vertinimas minètu metodu yra ribotas dèl socialinès naudos, neišmatuojamos piniginiais matais, neịtraukimo it vertinimą bei socialinès diskonto normos pasirinkimo nekonkretumo.

Apibūdinus visus kaštų naudos analizès metodo etapus, galima išskirti viešųjų projektų vertinimo minètu metodu trūkumus ir privalumus (3 pav.).

Daugiausia mokslinių diskusijų ir kritikos kaštų naudos analizès metodui skiriama dèl neịvertinamos visos viešųų projektų kuriamos socialinès naudos (neišmatuojamos piniginiais vienetais) bei socialinès diskonto normos nustatymo nekonkretumo.

\section{Viešųjų projektų socialinès naudos išmatavimo ir socialinès diskonto normos nustatymo problemos}

Mokslinejje literatūroje, kurioje analizuojami socialinių projektų vertinimo ypatumai, keliamas klausimas: kaip išmatuoti socialinę naudą? Svarbiausia problema įvertinant socialinę naudą - tai piniginès išraiškos suteikimas socialinès naudos veiksniams: kaip išmatuoti ne rinkos prekes, o, pvz., žmogaus gyvenimą, aplinkosaugos pokyčius?

Mokslininkai (Price, 1988; Bjornstad, Kahn, 1996; Constanza et al., 1997; Bateman, Willis,
1999; Jacoby, 2000; Nyborg, 2000; Huenemann, 2001; Glazer et al., 2002; Van de Walle, 2002) aktyviai diskutuoja, kokiais kiekybiniais ir kokybiniais rodikliais išreikšti viešųjų projektų socialinę naudą ir kokiais būdais kompleksiškai ją îvertinti.

Mokslininkai kelia klausimus: koks viešojo projekto poveikis yra ekonomiškai pagrịstas; kurie projekto padariniai turi būti įskaičiuoti; ar socialinè nauda reali ir reikšminga? Viena aišku, kad turi būti bent vienas asmuo, kuris yra geresneje ar blogesneje padètyje. Tie padariniai, kurie yra naudingi žmonèms, yra reikšmingi (ir įskaičiuotini). Skaičiuojamos vertès: socialinè nauda ir nuostoliai, ekologiniai padariniai, padidejusios galimybès (Constanza et al., 1997).

Svarbu tinkamas piniginis socialinio poveikio ivertinimas. Piniginiam vienetui suteikiama tik palyginamumo reikšmė atmetant nuostatą, kad pinigai yra viskas, kas turi reikšmę. Problema ta, kad dažnai rinkos kainos socialinėms pasekmèms neegzistuoja, nes aplinkos prekès yra viešos prekès. Kas turi būti daroma tais atvejais, kai kainos tiesiog neegzistuoja? Ekonominè literatūra siūlo du sprendimus. Pirma, naudojant kainas rinkoje esančių prekių ar paslaugų, kurios yra panašios ar gali būti keičiančios socialinę naudą. Skaičiavimams informacija yra gaunama iš rinkos duomenų. Antra, piniginès vertès informacija gali būti prilyginta žmonių galimybei sumokèti už socialinę naudą ar jų pasiruošimui priimti aplinkos ar socialinius padarinius. Šiuo atveju piniginès vertès informacija gali būti surasta atlikus žmonių poreikių bei galimybių analizę (Bjornstad, Kahn, 1996; Bateman, Willis, 1999).

Viešuosius projektus vertinant kaštų naudos metodu R. J. Just et al. (2004) siūlo taikyti hedonistinį metodą socialinei naudai išreikšti. Šis metodas paremtas numanomų rinkų analize. Prekių ar paslaugų, kurioms nèra rinkos, verte yra nustatoma analizuojant vartotojų elgseną su šiomis prekèmis ar paslaugomis susijusiose rinkose (numanomose rinkose). Teigiama, kad minèta vertè yra susijusi su rinkoje prekiaujamos prekès ar paslaugos, turinčios tam tikrą charakteristikų rinkinị, kaina (Taylor, 2003; Just et al., 2004).

Mokslininkai iš įvairių pasaulio šalių diskutuoja socialinès diskonto normos nustatymo klausimais: kokio dydžio diskonto normą reiktų pasirinkti vertinant viešuosius projektus; $\mathfrak{i}$ kokius veiksnius atsižvelgti pasirenkant socialinę diskonto normą; 


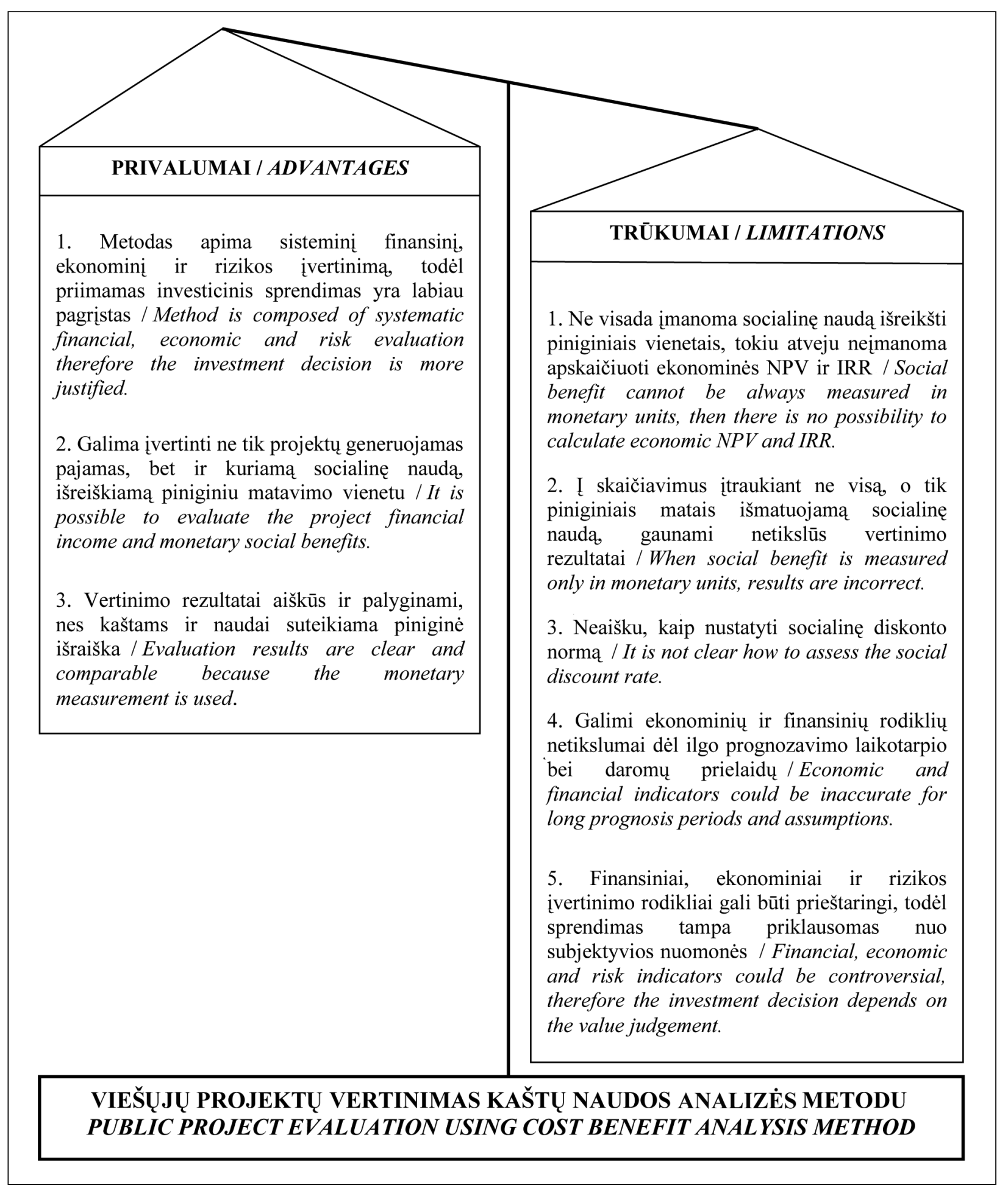

3 pav. Viešųų projektų vertinimo kaštų naudos analizės metodu privalumai ir trūkumai

Fig. 3. Advantages and limitations of the cost benefit analysis method used for evaluation of public projects

ar socialinè diskonto norma turètų būti pastovus dydis (konstanta) vertinant pinigu srautus visą projekto vertinimo laikotarpị; ar nereiktų taikyti skirtingų diskonto normų investiciniams kaštams ir projekto kuriamai naudai? Mokslinès diskusijos atskleidžia socialinès diskonto normos nustatymo problematiką, tačiau vieno aiškaus socialinès diskonto normos nustatymo metodo nepateikiama.

Diskutuojama apie šiuos diskonto normą sąlygojančius veiksnius ir jų ịvertinimą: diskontuotas 
visą gyvenimą trunkantis vartojimas; žmogiškasis kapitalas (diskontuota visą gyvenimą trunkanti produktyvi veikla); grynas įnašas ị visuomenę; mokumas (ekonomistai apskritai sutinka, kad tai yra geriausias matas). Mokumas priklauso nuo galimybių mokèti; rinkos trūkumų (pvz., nepilnos informacijos); pagrindinių teisių (pvz., turèti teisę ì sveiką aplinką); kitų rizikos veiksnių (pvz., potencialios klasterių aukos).

Kaip kiekvienas žmogus vertina ateiti priklauso nuo individualių aplinkybių bei rizikos. Taip grịžtama prie problemos nustatant atitinkamą diskonto normą. Didesnès socialinès diskonto normos nei reali grąžos norma nerizikingų investicijų nustatymas reikštų, kad gyventojai per daug taupo: jei žmonès taupo $2 \%$, bet diskontuoja savo būsimą vartojimą pagal aukštesnę normą, tai yra nelogiška. Nerizikingų investicijų norma turi būti naudojama kaip pagrindas socialinei diskonto normai, atsižvelgiant $\mathfrak{i}$ poveiki reikia diskontuoti ateities padarinius, bet neaukšta diskonto norma.

Socialinè diskonto norma priklauso nuo laikotarpio: kuo ilgesnis periodas, tuo mažesnè turi būti socialine diskonto norma. Viešųų projektų laikotarpis gali būti nuo 5 iki 100 metų ir ilgiau.

Analizuotos mokslinès literatūros autorių rekomenduojama naudoti socialiné diskonto norma pateikta lentelèje (varijuoja nuo 0 iki $7 \%$ ).

Mokslininkų nuomone, viešųjų projektų vertinimui naudojama socialinè diskonto norma turètų būti taikoma mažesnè nei verslo projektams bei naudojamos skirtingos diskonto normos investiciniams kaštams ir socialinei naudai, arba socialinè diskonto norma turi turèti mažèjimo tendenciją vertinant ilgo laikotarpio viešuosius projektus. Naujausioje literatūroje standartinis požiūris ị dis- kontavimą ekvivalentiška socialine diskonto norma nèra populiarus. Vyrauja nuomonè, kad viešųuc projektų diskontavimui turi būti taikoma dviguba diskonto norma.

Vadovaujantis Europos Komisijos darbo dokumentu Nr. 4 „Ekonominès naudos analizès atlikimo metodikos gairès“ (2006), Lietuvoje viešiesiems projektams iqvertinti ir palyginti naudojama 5,5 \% socialinè diskonto norma, susijusi su projektų palyginamumu, vertinimu, tačiau atsižvelgiant $\mathfrak{i}$ mokslininkų argumentus kyla abejonių, ar viešųju projektų ekonominio vertinimo rodikliams apskaičiuoti pasirinkta socialinè diskonto norma atspindi viešųjų projektų esmę, ilgą vertinamą laikotarpi, atidètą vartojimą, skirtingų kartų aspektą.

Mokslininkai diskutuoja dèl problemų, kylančių ịvertinant viešųjų projektų kuriamą socialinę naudą ir apskaičiuojant socialinę diskonto normą, konkrečių metodų problemai spręsti nepateikiama, todèl viešųjų projektų vertinimo, viešųju projektų socialinès naudos išmatavimo bei socialinès diskonto normos nustatymo klausimai gali būti aktuali mokslinių tyrimų tema.

\section{IŠVADOS}

1. Kaštų naudos analizès metodo esmè - lyginamos bent dvi alternatyvos: „be projekto“ ir „su projektu“ atliekant finansinę, ekonominę bei rizikos ir jautrumo analizę. Finansinès projekto analizès tikslas - parengti pinigų srautu prognozę bei apskaičiuoti finansinius rodiklius, kad būtu irodytas finansinis projekto gyvybingumas. Ekonominis vertinimas parodo projekto itaką regionui ar šaliai, t. y. teritorijai, kurioje projektas bus igyvendintas. Rizikos ir jautrumo analizè suteikia galimybę nustatyti rezultato kintamumą, pasikeitus

Le nt elè. Rekomenduojama socialinè diskonto norma

Table. Recommended social discount rate

\begin{tabular}{c|c}
\hline $\begin{array}{c}\text { Rekomenduojama socialinè diskonto } \\
\text { norma } \% \\
\text { Recommended social discount rate, \% }\end{array}$ & Šaltinis / Source \\
\hline $0 \%$ & C. Hepburn, 2006 \\
\hline $2 \%$ & V. Brukas, B. J. Thorsen, F. Helles, P. Tarp, 2001; C. Price, 2010 \\
\hline $1-3 \%$ & C. A. Sáez, J. C. Requena, 2007 \\
\hline $1,5-5 \%$ & Ch. Gollier 2002; 2010 \\
\hline $5,5 \%$ & $\begin{array}{c}\text { Europos Komisijos darbo dokumentas Nr. 4 „Ekonominès naudos } \\
\text { analizès atlikimo metodikos gairès“, 2006 }\end{array}$ \\
\hline $7 \%$ & Socialinių sąnaudų-naudos analizès metodinès gairès, 2011 \\
\hline
\end{tabular}


vieno veiksnio reikšmei, ir taip įvertinti projekto rizikingumą bei jautrumą. Vertinant viešuosius projektus ekonominè analizė yra svarbiausias kaštų naudos analizès metodo etapas, atskleidžiantis projekto sukuriamą socialinę naudą visuomenei. Didžiausias kaštų naudos analizès trūkumas - būtinybè socialinę naudą ịvertinti piniginiais matais, kas ne visais atvejais įmanoma.

2. Viešųjų projektų vertinimui naudojamo kaštų naudos analizės metodo esminiai privalumai:

- metodas apima sisteminį finansinit, ekonominị ir rizikos ịvertinimą;

- galima iqvertinti ne tik projektu generuojamas pajamas, bet ir kuriamą socialinę naudą, išreiškiamą piniginiu matavimo vienetu;

- vertinimo rezultatai aiškūs ir palyginami - naudojama piniginè išraiška.

Pagrindiniai kaštų naudos analizès metodo trūkumai:

- ne visada imanoma socialinę naudą išreikšti piniginiais vienetais;

- $\quad$ i skaičiavimus įtraukiant ne visą, o tik piniginiais matais išmatuojamą socialinę naudą, gaunami netikslūs vertinimo rezultatai;

- neaišku, kaip nustatyti socialinę diskonto normą;

- galimi ekonominių ir finansinių rodiklių netikslumai dèl ilgo prognozavimo laikotarpio bei daromų prielaidų;

- finansiniai, ekonominiai ir rizikos ịvertinimo rodikliai gali būti prieštaringi, todèl sprendimas tampa priklausomas nuo subjektyvios nuomonès.

3. Mokslinèse diskusijose keliami šie viešųju projektų socialinès naudos îvertinimo probleminiai klausimai:

- kokia viešųų projektų kuriama socialinè nauda yra reikšminga;

- kokiais kiekybiniais ir kokybiniais rodikliais socialinę naudą išreikšti;

- $\quad$ kokiais būdais ir metodais socialinè nauda gali būti įvertinta;

- kaip iqvairiais matavimo vienetais iqvertintą viešojo projekto socialinę naudą apjungti $\mathfrak{i}$ vieną palyginamą rodiklį?

Analizuotos mokslinès literatūros autorių viešųjų projektų vertinimui rekomenduojama naudoti socialiné diskonto norma varijuoja nuo 0 iki $7 \%$. Mokslinès diskusijos atskleidžia socialinès diskonto normos nustatymo problematiką:
- $\quad$ kokie veiksniai turi itakos pasirenkant socialinę diskonto normą viešųjų projektų vertinimui;

- $\quad$ kokiais būdais, metodais nustatyti socialinę diskonto normą;

- ar socialinè diskonto norma turi būti konstanta visą projekto gyvavimo laikotarpit;

- ar vienoda socialiné diskonto norma turi būti taikoma investiciniams kaštams bei socialinei naudai?

4. Apibendrinant galima teigti, jog kaštų naudos analizès metodas labiau tinkamas verslo projektams, o ne viešiesiems projektams vertinti. Dèl socialinès naudos neišmatuojamumo piniginiais vienetais, kaštų naudos analizès metodu apskaičiuoti rodikliai tik iš dalies atskleidžia vertinamą projektą - visuomenini interesą, o netinkamas socialinès diskonto normos nustatymas dar labiau iškreipia projekto rodiklius projekto vertinimo laikotarpiu. Kaštų naudos analizès metodas viešiesiems projektams vertinti turi būti tobulinamas integruojant su kitais vertinimo metodais, modeliuojant situacijas. Šiame straipsnyje susistemintos pagrindinès koncentruotos mokslo teorinès žinios, apibrèžtas mokslinis probleminis laukas viešujų projektų vertinimo kaštų naudos analizès metodo tobulinimui ar nauju metodų kūrimui.

Gauta 20130303

Priimta 20130424

\section{LITERATŪRA}

1. Baranauskiene J., Maziliauskas A. 2012. Socialinès naudos daugiakriterinis vertinimas vandentvarkos projektuose. Apskaitos ir finansu mokslas ir studijos: problemos ir perspektyvos. Nr. 1(8). P. 21-27.

2. Baranauskienè J. 2004. Išlaidų-naudos analizès metodo taikymas, rengiant viešojo sektoriaus investicinius projektus. Apskaitos ir finansu mokslas ir studijos: problemos ir perspektyvos. Nr. 1(4). P. 135-137.

3. Bateman I. J., Willis K. G. 1999. Valuing Environmental Preferences. Oxford: Oxford University Press.

4. Bjornstad D. J., Kahn J. R. 1996. The Contingent Valuation of Environmental Resources. Cheltenham: Edward Elgar.

5. Boardman A., Greenberg D., Vining A, Weimer D. 2006. Cost-Benefit Analysis: Concepts and Practice. Upper Saddle River, NJ: Prentice Hall. 
6. Brukas V., Thorsen B. J., Helles F., Tarp P. 2001. Discount rate and harvest policy: implications for Baltic forestry. Forest Policy and Economics. Vol. 2. P. 143-156 [žiūrèta 2012-11-21]. Prieiga per duomenu bazę ScienceDirect: http://www.sciencedirect.com/

7. Constanza R., et al. 1997. The value of the world's ecosystem services and nature capital. Nature. Vol. 387. P. 253-260 [žiūrèta 2012-11-21]. Prieiga per duomenu baze ScienceDirect: http://www. sciencedirect.com/

8. Eckstein O. 1958. Water Resource Development: The Economics of Project Evaluation. Cambridge, M. A: Harvard University Press.

9. Glazer A., Kanniainen V., Niskanen E. 2002. Bequests, control rights, and cost-benefit analysis. European Journal of Political Economy. Vol. 19. P. 71-82 [žiūrèta 2012-12-12]. Prieiga per duomenu bazę ScienceDirect: http://www.sciencedirect.com/

10. Gollier Ch. 2002. Discounting an uncertain future. Journal of Public Economics. Vol. 85. P. 149-166 [žiūrèta 2012-11-22]. Prieiga per internetą: http:// www.sciencedirect.com/

11. Gollier Ch. 2010. Ecological discounting. Journal of Economic Theory. Vol. 145. P. 812-829 [žiūrèta 2012-12-15]. Prieiga per duomenu bazę ScienceDirect: http://www.sciencedirect.com/

12. Guidance on the Methodology for Carrying out Cost-Benefit Analysis. Working Document No. 4. 2006. European Commission, Directorate-General Regional Policy. P. 1-23.

13. Guide to Cost-Benefit Analysis of Investment Projects. Structural Funds, Cohesion Fund and Instrument for Pre-Accession. Final Report. 2008. P. 1-255.

14. Hanemann W. M. 1994. Valuing the environment through contingent valuation. Journal of Econonomic Perspectives. Vol. 8. P. 19-43 [žiūrèta 2013-01-21]. Prieiga per duomenu bazę ScienceDirect: http://www.sciencedirect.com/

15. Hanley N., Spash C. 1993. Cost-Benefit Analysis and the Environment. Cheltenham: Edward Elgar.

16. Hansjugen B. 2004. Economic valuation through cost-benefit analysis - possibilities and limitations. Toxicology. Vol. 205. P. 241-252 [žiūrèta 2013-0211]. Prieiga per duomenu bazę ScienceDirect: http://www.sciencedirect.com/

17. Hauer E. 2011. Computing what the public wants: Some issues in road safety cost-benefit analysis. Accident Analysis and Prevention. Vol. 43. P. 151164 [žiūrèta 2012-12-12]. Prieiga per duomenu baze ScienceDirect: http://www.sciencedirect. $\mathrm{com} /$

18. Henderson N., Bateman I. 1995. Empirical and public choice evidence for hyperbolic social discount rates and the implications for intergenerational discounting. Environmental and Resource
Economics. Vol. 5. P. 413-423 [žiūrèta 2013-0210]. Prieiga per duomenu bazę ScienceDirect: http://www.sciencedirect.com/

19. Hepburn C. J., Koundouri P. 2007. Recent advances in discounting: Implications for forest economics. Journal of Forest Economics. Vol. 13. P. 169-189 [žiūrèta 2013-01-28]. Prieiga per duomenu bazę ScienceDirect: http://www.sciencedirect.com/

20. Investiciju projektu, kuriems siekiama gauti finansavima iš ES struktūriniu fondu ir valstybès biudžeto lëšu, rengimo metodika, 2011. Všt Centrinè projektų valdymo agentūra. P. 1-37.

21. Jacoby H. G. 2000. Access to markets and the benefits of rural roads. The Economic Journal. Vol. 110. P. 713-737 [žiūrèta 2013-01-28]. Prieiga per duomenu bazę ScienceDirect: http://www.sciencedirect.com/

22. Johansson P. O. 1993. Cost-Benefit Analysis of Environmental Change. Cambridge: Cambridge University Press.

23. Just R. J., Hueth D. L., Schmitz A. 2004. The Economics of Public Policy: A Practical Quide to Policy and Project Evaluation. Cheltenham, UK: Edwin Elgar Press.

24. Liu L. 2003. A marginal cost of funds approach to multi-period public project evaluation: implications for the social discount rate. Journal of Public Economics. Vol. 87. P. 1707-1718 [žiūrèta 201212-12]. Prieiga per duomenu bazę ScienceDirect: http://www.sciencedirect.com/

25. Marglin S. A. 1967. Public Investment Criteria. Boston: MIT Press.

26. McGuire M., Garn H. 1969. The integration of equity and efficiency criteria in public project selection. Economic Journal. Vol. 79(136). P. 882-93 [žiūrèta 2013-01-28]. Prieiga per duomenu bazę ScienceDirect: http://www.sciencedirect.com/

27. Nyborg K. 2000. Project analysis as input to public debate: Environmental valuation versus physical unit indicators. Ecological Economics. Vol. 34. P. 393-408 [žiūrèta 2013-01-28]. Prieiga per duomenu bazę ScienceDirect: http://www.sciencedirect.com/

28. Nooij M. 2011. Social cost-benefit analysis of electricity interconnector investment: A critical appraisal. Energy Policy. Vol. 39. P. 3096-3105 [žiūrèta 2013-01-12]. Prieiga per duomenų bazę ScienceDirect: http://www.sciencedirect.com/

29. Pearce D. W., Atkinson G., Mourato S. 2006. CostBenefit Analysis and the Environment: Recent Developments. Paris: Organisation for Economic and Co-operative Development.

30. Price C. 1988. Investment, reinvestment and the social discount rate for forestry. Forest Ecology and Management. Vol. 24. P. 293-310 [žiūrèta 201301-28]. Prieiga per duomenu bazę ScienceDirect: http://www.sciencedirect.com/ 
31. Price C. 2010. Low discount rates and insignificant environmental values. Ecological Economics. Vol. 69. P. 1895-1903 [žiūrèta 2012-01-21]. Prieiga per duomenu bazę ScienceDirect: http://www.sciencedirect.com/

32. Ray A. 1984. Cost-Benefit Analysis: Issues and Methodologies. Baltimore, MD: Johns Hopkins University Press.

32. Rosen H. S., Gayer T. 2008. Public Finance. New York: McGraw-Hill.

34. Sáez C. A., Requena J. C. 2007. Reconciling sustainability and discounting in Cost-Benefit Analysis: A methodological proposal. Ecological Economics. Vol. 60. P. 712-725 [žiūrèta 2012-12-12]. Prieiga per duomenu bazę ScienceDirect: http://www.sciencedirect.com/

35. Socialiniu sąnaudu-naudos analizès metodinès gairès 2011. Lietuvos Respublikos Vyriausybè [žiūrèta 2012-01-21]. Prieiga per interneta: http://www.lrv. lt/Vyriausybes\%20gidas/6_Sanaudu\%20metodines\%20gaires.pdf

36. Sugden R., Williams A. 1978. The Principles of Practical Cost-Benefit Analysis. Oxford: Oxford University Press.

37. Taylor L. O. 2003. The Hedonic Method. In: A Primer on Nonmarket Valuation. P. 331-393 [žiūrèta 2013-01-12]. Prieiga per duomenu bazę ScienceDirect: http://www.sciencedirect.com/

38. Van de Walle D. 2002. Choosing rural road investments to help reduce poverty. World Development. Vol. 30. No. 4. P. 575-589.
Jurgita Baranauskienè

\section{PUBLIC PROJECT EVALUATION USING THE COST BENEFIT ANALYSIS METHOD: A CRITICAL APPROACH}

Sum mary

Public investment projects, in contrast to private investment projects, do not generate net income (or generate not enough to be financially justified), but create social benefits for the society. The main purpose of these projects is satisfaction of public needs: social, economic, environmental. In a broad sense, this is public or social benefit. Every project must be evaluated and justified in order to make the investment decision. The cost benefit analysis is a common method for public project evaluation, but this method does not fully comply with the basic concept of public projects. The most actual problem of the cost benefit analysis is conversion of qualitative indicators of public benefit (for example, human life) into quantitative and monetary measures. It must be noted that public project evaluation using the cost benefit analysis method could be partial - cost benefit analysis, carried out perfectly, does not solve the problem, i. e. all social benefits, created by the public project, are not counted even if social benefit is the main purpose of the public project.

This theoretical research disclosed limitations of the cost benefit analysis method, used for public projects evaluation, and identified the problem field for potential researches - for improving the cost benefit analysis method or creating new methods in order to evaluate public investment projects.

Key words: cost benefit analysis, public project, social benefit, social discount rate 